\title{
Ecophysiology of the Mediterranean mussel Mytilus galloprovincialis L; effect of different microalgae diets and ration on broodstock conditioning
}

\author{
Hidaya Drissou ${ }^{1}$, Yassine Ouagajjou ${ }^{2}$, and Adil Aghzar ${ }^{3, *}$ \\ ${ }^{1}$ Faculty of Science, Abdelmalek Essaadi University, Tétouan 93002, Morocco \\ ${ }^{2}$ Amsa Shellfish Station, National Institute of Fisheries Research (INRH), Amsa, Tétouan, 93022, Morocco \\ ${ }^{3}$ Higher School of Technology, Sultan Moulay Slimane University, Khénifra 54000, Morocco
}

\begin{abstract}
Three diets based on three microalgae species (Tetraselmi ssuecica, Isochrysis galbana, and Chaetoceros calcitrans) and three feeding rations (1\%, 2\%, and 3\%) were used to understand the ecophysiology of the Mediterranean mussel Mytilus galloprovincialis during Broodstock conditioning. Generally, mussels increase their consumption regarding food availability for all diets, and it is evident that the highest consumption was recorded with a feed ratio of $3 \%$. During the study, I. galbana and $C$. calcitrans strains show the high consumption $\left(1.58 \mu \mathrm{g} . \mathrm{g}^{-1} \cdot \mathrm{h}^{-1} \pm 0.00\right)$ and $\left(1.58 \mu \mathrm{g} \cdot \mathrm{g}^{-1} \cdot \mathrm{h}^{-1} \pm 0.00\right)$ compared with $T$. suecica $\left(1.542 \mu \mathrm{g}\right.$. $\mathrm{g}^{-1}$. $\left.\mathrm{h}^{-1} \pm 0.023\right)$ recorded at $3 \%$ food ration of monospecific diets. Same results were recorded for ingestion but with great learning for $I$. galbana in triscpecific diet $\left(0.70 \mu \mathrm{g} . \mathrm{g}^{-1} . \mathrm{h}^{-1}\right.$ $\pm 0.052)$ compared to $C$. calcitrans $\left(0.36 \mu \mathrm{g} . \mathrm{g}^{-1} \cdot \mathrm{h}^{-1} \pm 0.037\right)$ and $T$. suecica $\left(0.25 \mu \mathrm{g} . \mathrm{g}^{-1} \cdot \mathrm{h}^{-1} \pm 0.126\right)$, respectively. The analysis of ANOVA has shown that both diet and food availability affect significantly the ingestion $(\mathrm{F}=30.9, \mathrm{df}=2, p<0.001$ and $\mathrm{F}=4.4, \mathrm{df}=6, p<0.001)$ during mussel conditioning.
\end{abstract}

\section{Introduction}

The Mediterranean mussel Mytilus galloprovincialis distributed along the Moroccan coasts [1,2] is an incredible gastronomic and economic interest species. The development of mussel farming is based on the availability of wild spat $[3,4]$. Therefore, the availability of wild spat has played a crucial role in the mussel industry [5], and such availability is becoming a critical bottleneck because of the impact of scraping on natural beds [6]. This situation has given rise to different studies such as new spat collectors and rearing devices (e.g. [7]) and reproduction in captivity $[8,9]$.

The conditioning process is mainly based on the feeding management of broodstock and depends highly on the choice of the appropriate microalgae diets in terms of quality and food availability (ration) required for maturation in broodstock conditioning. Many studies on ecophysiology were performed to optimize feeding regimes and rations on conditioning and explain the effect of each physiological aspect $[10,11]$. The present research aimed to evaluate the effect of multispecific microalgae diets and suitable food ration on physiological parameters like consumption and ingestion of the Mediterranean mussel broodstock.

\section{Materials and Methods}

\subsection{Mussel sampling and broodstock conditioning}

The biological material consisted of $(28 * 10)$ adult specimens of the local mussel (weight $=23,41 \pm 5,10 \mathrm{~g}$; length $=66,74 \pm$ $5,86 \mathrm{~mm}$ ) collected from natural populations from M'diq (234' $26^{\prime \prime}$ N $/ 15^{\circ} 44^{\prime} 26^{\prime \prime}$ M'diq, Morocco), then rinsed and placed in $20 \mathrm{~L}$ tanks and held in a closed water system. An average of 10 individuals per tank was used for each experiment under natural conditions of temperature $\left(20^{\circ} \mathrm{C}\right)$, salinity (36 PSU), $\mathrm{pH}(8-8,3)$, and dissolved oxygen $(6.4$ $\pm 0.5 \mathrm{mg} / \mathrm{L}$ ). Forty adults were randomly chosen in order to calculate their mean dry weight. Before carrying out feeding tests, all adults were held to fast for $48 \mathrm{~h}$ in order to get rid of their feces.

\subsection{Feeding process}

Live microalgae used in this study consist of three species (Isochrysis galbana, Chaetoceros calcitrans, et Tetraselmis suecica). The choice of these three species is based on their high nutrient richness. Three diets, monospecific (M), bispecific (B), and tri-specific (T), were used during this experiment with different compositions. Three monospecific (M1:100\% $\mathrm{T}$.

\footnotetext{
*Corresponding author: a.aghzar@usms.ma
} 
suecica; M2: 100\% I. galbana and M3: $100 \% C$. calcitrans), three bispecific (B1: 25\% T. suecica $+75 \%$ I. galbana; B2: $25 \%$ T. suecica $+75 \%$ C. calcitrans and B3: $50 \%$ I. galbana $+50 \%$ C. calcitrans) and one Trispecific regimes (T: $25 \%$ T. suecica $+75 \%$ I. galbana $+25 \%$ C. calcitrans). Furthermore, for each diet, we established seven feeding rations in triplicate as described by [12] $(1 \%, 2 \%, 3 \%$ of dry mussel weight $)$ in addition to controlling diet ( $0 \%$ : only natural seawater). The pseudofeces occurrence was taken calculated according to [13].

\subsection{Statistical analyses}

In order to estimate the effect of each treatment (diet and ration) on each calculated parameter, a two-way analysis of variance (ANOVA) was performed at a 95\% level of confidence $(\alpha=0.05)$. When ANOVAs were significant, the post hoc Tukey multiple comparison tests were used to determine which treatments differed. All statistical tests were analyzed using the Rcmdr interface [14] implemented in R package version 3.1.2 [15].

\section{Results}

\subsection{Consumption within diets and rations}

Table 1 shows the feeding behavior of mussels in terms of consumption according to diets and rations. Generally, for all diets $\mathrm{M}, \mathrm{B}$ and $\mathrm{T}$, we observe that mussels increase their consumption regarding food availability, and the highest consumption was recorded with feed ration 3\%. Within monospecific diets, mussels showed a small tendency towards I. galbanain terms of consumption $\left(1.58 \mu \mathrm{g} . \mathrm{g}^{-1} \cdot \mathrm{h}^{-1} \pm 0.00\right)$ and $C$. calcitrans $\left(1.58 \mu \mathrm{g} . \mathrm{g}^{-1} \cdot \mathrm{h}^{-1} \pm 0.00\right)$ strains compared to $T$. suecica (1.542 $\left.\mu \mathrm{g} . \mathrm{g}^{-1} \cdot \mathrm{h}^{-1} \pm 0.023\right)$ at $3 \%$ food ration. For bispecific diets, and across all three diets tested, strains more consumed by mussel are $C$. calcitrans $\left(1.18 \mu \mathrm{g}\right.$. $\mathrm{g}^{-}$ $\left.{ }^{1} . \mathrm{h}^{-1} \pm 0.00\right)$ inDiet B2 and I. galbana $\left(1.17 \mu \mathrm{g} . \mathrm{g}^{-1} \cdot \mathrm{h}^{-}\right.$ $\left.{ }^{1} \pm 0.01\right)$ in Diet B1. However, T. suecica showed the lowest consumption $\left(0.4 \mu \mathrm{g} . \mathrm{g}^{-1} \cdot \mathrm{h}^{-1} \pm 0.00\right)$ regarding the number of microalgae assimilated by mussels for all food rations and mixture diets. Whereas, the most important result obtained in this study is the high consumption $\left(0.788 \mu \mathrm{g}\right.$. $\left.\mathrm{g}^{-1} \cdot \mathrm{h}^{-1} \pm 0.00\right)$ recorded in $I$. galbana in trispecific diet $(\mathrm{T})$ at $3 \%$ food ratio $(50 \%$ of total consumed biomass) and the other strains are equally consumed ( $25 \%$ of total consumed biomass).

Table 1. Consumption of microalgae (g dry weight algae) per dry weight of mussel M. galloprovincialis reared under different diets and food rations

\begin{tabular}{|c|c|c|c|c|}
\hline \multirow{2}{*}{ Diet } & \multirow{2}{*}{ Strain } & \multicolumn{3}{|c|}{ Consumption $(\boldsymbol{\mu g}$. g-1. h-1) \pm SD } \\
\cline { 3 - 5 } & & $\mathbf{1 \%}$ & $\mathbf{2 \%}$ & $\mathbf{3 \%}$ \\
\hline \multirow{2}{*}{ M1 } & \multirow{2}{*}{ T. suecica } & $\begin{array}{c}0.527( \pm \\
0.000)\end{array}$ & $\begin{array}{c}0.681 \\
( \pm 0.018)\end{array}$ & $\begin{array}{c}1.542 \\
( \pm 0.024)\end{array}$ \\
\hline \multirow{2}{*}{ M2 } & \multirow{2}{*}{ I. galbana } & $\begin{array}{c}0.525( \pm \\
0.000)\end{array}$ & $\begin{array}{c}1.027( \pm \\
0.022)\end{array}$ & $1.58( \pm 0.000)$ \\
\hline \multirow{2}{*}{ M3 } & C. & $0.526( \pm$ & $1.052( \pm$ & $1.58( \pm 0.000)$ \\
\hline
\end{tabular}

\begin{tabular}{|c|c|c|c|c|}
\hline & calcitrans & $0.000)$ & $0.000)$ & \\
\hline \multirow{3}{*}{ B1 } & T. suecica & $\begin{array}{c}0.132 \\
( \pm 0.000)\end{array}$ & $0.26( \pm 0.00)$ & $0.4( \pm 0.000)$ \\
\hline & I. galbana & $0.39( \pm 0.00)$ & $\begin{array}{c}0.78 \\
( \pm 0.06 .10-4)\end{array}$ & $1.17( \pm 0.001)$ \\
\hline & Total & $0.52( \pm 0.00)$ & $1.04( \pm 0.009)$ & $1.57( \pm 0.001)$ \\
\hline \multirow{3}{*}{ B2 } & T. suecica & $\begin{array}{c}0.131 \\
( \pm 0.000)\end{array}$ & $0.26( \pm 0.00)$ & $0.4( \pm 0.00)$ \\
\hline & $\begin{array}{c}\text { C. } \\
\text { calcitrans }\end{array}$ & $0.39( \pm 0.00)$ & $0.78( \pm 0.00)$ & $1.18( \pm 0.00)$ \\
\hline & Total & $0.52( \pm 0.00)$ & $1.04( \pm 0.00)$ & $1.58( \pm 0.00)$ \\
\hline \multirow{3}{*}{ B3 } & I. galbana & $0.26( \pm 0.00)$ & $0.52( \pm 0.00)$ & $0.75( \pm 0.009)$ \\
\hline & $\begin{array}{c}\mathrm{C} . \\
\text { calcitrans } \\
\end{array}$ & $0.26( \pm 0.00)$ & $0.52( \pm 0.00)$ & $\begin{array}{c}0.78(0.06 .10- \\
4)\end{array}$ \\
\hline & Total & $0.52( \pm 0.00)$ & $1.04( \pm 0.00)$ & $1.53( \pm 0.009)$ \\
\hline \multirow{4}{*}{$\mathrm{T}$} & T. suecica & $0.13( \pm 0.00)$ & $\begin{array}{c}0.263 \\
( \pm 0.6 .10-3) \\
\end{array}$ & $0.39( \pm 0.00)$ \\
\hline & I. galbana & $0.263( \pm 0.00)$ & $0.525( \pm 0.00)$ & $0.788( \pm 0.00)$ \\
\hline & $\begin{array}{c}\mathrm{C} . \\
\text { calcitrans }\end{array}$ & $0.13( \pm 0.00)$ & $\begin{array}{c}0.263 \\
( \pm 0.009)\end{array}$ & $0.4( \pm 0.00)$ \\
\hline & Total & $0.527( \pm 0.00)$ & $\begin{array}{c}1.052 \\
( \pm 0.6 .10-3)\end{array}$ & $\begin{array}{c}1.572 \\
( \pm 0.000)\end{array}$ \\
\hline \multicolumn{2}{|c|}{ Seawater } & \multicolumn{3}{|c|}{$0.137( \pm 0.052)$} \\
\hline
\end{tabular}

\subsection{Ingestion within diets and rations}

In terms of ingestion, generally, the occurrence of pseudofeces is almost rare in all cases, which means that mussels ingested the number of consumed microalgae. The statistical analysis of the effect of both diets and food availability on ingestion has been carried out during this study (table. 2).

Table 2. Effect of diets and food availability on ingestion during broodstock conditioning. Df (Degree of freedom), SumSq (Sum of Square), Sq (Square), F (F value), *** (significant at $\mathrm{P}<0.001$ ).

\begin{tabular}{|c|c|c|c|c|c|}
\hline & Df & SumSq & Mean sq & F & $\operatorname{Pr}(>\mathbf{F})$ \\
\hline Ration & 2 & $6.2 \times 10-12$ & $\begin{array}{c}3.10 \times 10- \\
12\end{array}$ & $30.9 * * *$ & $\begin{array}{c}2.78 \times 10- \\
11\end{array}$ \\
\hline Diets & 6 & $\begin{array}{c}6.46 \times 10- \\
12\end{array}$ & $\begin{array}{c}1.08 \times 10- \\
12\end{array}$ & $4.4 * * *$ & $4.8 \times 10-4$ \\
\hline Type of diets & 2 & $\begin{array}{c}6.26 \times 10- \\
12\end{array}$ & $\begin{array}{c}3.13 \times 10- \\
12\end{array}$ & $12.7 * * *$ & $\begin{array}{c}1.07 \times 10- \\
5\end{array}$ \\
\hline Ration/diets & 20 & $6.3 \times 10-12$ & $\begin{array}{c}3.24 \times 10- \\
12\end{array}$ & $31.5 * * *$ & $\begin{array}{c}2.2 \times 10- \\
16\end{array}$ \\
\hline
\end{tabular}

The food availability has most significantly influenced the ingestion of microalgae during mussels conditioning than diets ( $\mathrm{F}=30.9$ and $\mathrm{F}=4.4$, respectively). However, we observed that the type of diets $(\mathrm{M}, \mathrm{B}$, and $\mathrm{T})$ have also greatly influenced the ingestion of microalgae $(\mathrm{F}=12.7)$. In contrast, ingestion of microalgae was highly affected by both diets and ration $(\mathrm{F}=31.5)$.

\section{Discussion}

Food diets composition and rations (1\%,2\%, and 3\%) have shown different physiological parameters in the mussel broodstock. Both consumption and ingestion 
were increased within all diets regarding food rations that the food availability can explain. The tendency towards I. galbana and C. calcitrans strains compared to $T$. suecica can be explained by factors such as cell size, digestibility, and biochemical composition. Such factors determine the nutritive quality of the microalgae and their utility as food for bivalves [16, 17, 18]. Similar results were found in other bivalve species such as Crassostrea virginica [19], Pectenmaximus [20], and Ventricosus circularis [21].

For example, [22] demonstrated that the combination diet (I. galbana $+C$. calcitrans) at $22{ }^{\circ} \mathrm{C}$ was the best diet to give a maximal reproductive performance that fits our study well. This is explained by the fact that $I$. galbana had a higher percentage of lipids, but the combination with $C$. calcitrans was better than $I$. galbana alone due to the high percentage of carbohydrates accumulated in $C$. calcitrans cells. The microalgae I.galbana has reported an excellent food either in monospecific or multispecific diets [22]. Studies have shown that not all microalgae species are readily ingested by bivalve [23, 24]; the fact that particular microalgae species are consumed $\mathrm{d}[$ oes not necessarily mean they are ingested.

\section{Conclusion}

Despite the general recognition that a mixed microalgal diet gives better nutritional values for the conditioned bivalves, it is limited by the need for selection of algal strain used with suitable particle size, digestibility, and nutritive composition to get the total expected benefit of the mixed diets for bivalve hatcheries. Results and observations of the present study indicated that $I$. galbana and C. calcitrans had competitive conditioning performance, and the mixture of both had the highest conditioning potentiality as a diet for $M$. galloprovincialis broodstock conditioning. Therefore, $T$. suecica can be recommended for broodstock conditioning in the hatchery. I. galbana and $C$. calcitrans are recommended in bispecific diets, and $I$. galbana is more recommended in triscpecific diets. While, regarding food availability, more research is required to reveal the optimal ratio for mussels broodstock during the conditioning process.

\section{References}

1. H. Jaziri , T. Benazzou C. R. Biologies 325: 11751183 (2002)

2. Y. Ouagajjou, P. Presa. Estuar. Coast. Shelf Sci., 152: 1-10 (2015)

3. L.S Incze, R.A Lutz. Mussel culture: an east coast perspective. Pp. 99-140. In: R.A Lutz (ed.). Mussel Culture and Harvest: A North American
Perspective. Elsevier Sci. Publ. Co., Amesterdam (1980)

4. R.W. Hickman, Mussel cultivation. In: The mussel Mytilus: ecology, physiology, genetics and culture [ed. by Gosling, E]. Amsterdam, The Netherlands: Elsevier Science Publishers BV.465-510 (1992)

5. J. Caceres-Martinez, A. Figueras, J Shellfish Res. 17:153-157 (1998)

6. M. Holmer, K. Black, C.M. Duarte, N. Marba, I. Karakassis, Aquaculture in the Ecosystem. Netherlands: Springer (2008)

7. A. Aghzar, M. Talbaoui, M.H. Benajiba, P. Presa, Mar. Freshw. Behav. Physiol. 45: 51-61 (2012)

8. P. Kamermans, T. Galley, P. Boudry, J. Fuentes, H. McCombie, F. Batista, A. Blanco, L. Dominguez, F. Cornette, Elsevier, New York, pp 339-373 (2013)

9. A. Aghzar, M. Miñambres, P. Alvarez, P. Presa, Thalassas 29: 9-16 (2013)

10. J.I.P. Iglesias, M.B. Urrutia, E. Navarro, I. Ibarrola, J. Exp. Mar. Biol. Ecol. 219: 71-86 (1998)

11. I. Martínez-Pita, C. Sánchez-Lazo, F.J. García, Aquacult. Nutr., 22 202-216 (2016)

12. S.D. Utting, P.F. Millican, Aquaculture, 155 : 45-54 (1997)

13. R. Beiras, A. Pérez-Camacho, Mar. Biol. 120:427435 (1994)

14. J. Fox, Bouchet-Valat, M. Rcmdr. R Commander. R package version 2.3-1 (2016)

15. R DevelopmentCore Team. R: RFoundation for Statistical Computing, Vienna, Austria 2008, ISBN 3-900051-07-0, URL (2008)

16. G. Owen, Adv Comp Physiol Biochem $5: 1-35$ (1974)

17. J.W Ewart, C.E Epifanio, Aquaculture 22:297-300 (1981)

18. M. Albentosa, A. Perez-Camacho, U. Labarta, R. Beiras, M.J. Fernández-Reiriz Mar Ecol Prog Ser 97: 261-269 (1993)

19. J. Babinchak, R. Ukeles Mar. Biol. 51: 69-76 (1979)

20. M. Le Pennec, C. Rangel-Davalos, Aquaculture, 47 : $39-51(1985)$

21. M.C. Lora-Vilchis, A.N. Maeda-Martinez, Aquac. Res. 28 :905 - 910 (1997)

22. D. Matias, S. Joaquim, A.M. Matias, A. Leitão Invertebr Reprod Dev, 60:49-58 (2016)

23. J. Babinchak, R. Ukeles, Mar. Biol., 51: 69-76 (1979)

24. M.C. Lora-Vilchis, A.N. Maeda-Martinez, Aquac. Res. 28 : 905 - 910 (1997) 